\title{
Diesel exhaust particulate increases the size and complexity of lesions in atherosclerotic mice
}

\author{
Mark R Miller ${ }^{1 *}$, Steven G McLean ${ }^{1}$, Rodger Duffin², Akeem O Lawal ${ }^{3}$, Jesus A Araujo ${ }^{3}$, Catherine A Shaw ${ }^{1}$, \\ Nicholas L Mills', Ken Donaldson², David E Newby ${ }^{1}$ and Patrick WF Hadoke ${ }^{1}$
}

\begin{abstract}
Objective: Diesel exhaust particulate (DEP), a major component of urban air pollution, has been linked to atherogenesis and precipitation of myocardial infarction. We hypothesized that DEP exposure would increase and destabilise atherosclerotic lesions in apolipoprotein $\mathrm{E}$ deficient $\left(\mathrm{Apo}^{-/-}\right)$mice.

Methods: ApoE ${ }^{-/-}$mice were fed a 'Western diet' (8 weeks) to induce 'complex' atherosclerotic plaques, with parallel experiments in normal chow fed wild-type mice. During the last 4 weeks of feeding, mice received twice weekly instillation (oropharyngeal aspiration) of $35 \mu \mathrm{L}$ DEP (1 mg/mL, SRM-2975) or vehicle (saline). Atherosclerotic burden was assessed by en-face staining of the thoracic aorta and histological examination of the brachiocephalic artery.

Results: Brachiocephalic atherosclerotic plaques were larger in $\mathrm{ApoE}^{--}$mice treated with DEP (59 $\left.\pm 10 \%\right)$ than in controls $(32 \pm 7 \% ; P=0.017)$. In addition, DEP-treated mice had more plaques per section of artery $(2.4 \pm 0.2$ vs $1.8 \pm 0.2 ; P=0.048)$ and buried fibrous layers $(1.2 \pm 0.2 \mathrm{vs} 0.4 \pm 0.1 ; P=0.028)$. These changes were associated with lung inflammation and increased antioxidant gene expression in the liver, but not with changes in endothelial function, plasma lipids or systemic inflammation.

Conclusions: Increased atherosclerosis is caused by the particulate component of diesel exhaust producing advanced plaques with a potentially more vulnerable phenotype. These results are consistent with the suggestion that removal of the particulate component would reduce the adverse cardiovascular effects of diesel exhaust.
\end{abstract}

Keywords: Diesel, Air pollution, P, Atherosclerosis, ApoE, Oxidative stress

\section{Background}

Particulate matter (PM) air pollution is associated with an increase in cardiovascular morbidity and mortality [1,2]. In epidemiologic studies, residents of areas with high air pollution have evidence of increased atherosclerosis [3-6]. This relationship is supported by pre-clinical studies showing that exposure to traffic-derived pollutants can increase atherosclerotic lesion size and alter lesion composition (comprehensively reviewed in [7]). The mechanisms responsible for these changes remain unclear, but there is evidence implicating altered endothelial cell function [8] and increased oxidative stress [9-11].

\footnotetext{
* Correspondence: mark.miller@ed.ac.uk

${ }^{1}$ Centre for Cardiovascular Sciences, University of Edinburgh, 47 Little France Crescent, EH16 4TJ Edinburgh, Scotland, UK

Full list of author information is available at the end of the article
}

Diesel exhaust (DE) emissions are the major source of nanoparticles in the urban environment that, while contributing little to the airborne mass, produce very high numbers of ambient particles and a large reactive surface area, as well as the potential to deposit throughout the lungs $[12,13]$. We have previously shown that inhalation of environmentally-relevant concentrations of DE impairs endothelial and fibrinolytic function $[14,15]$, promotes blood thrombogenicity [16] and exacerbates cardiac ischemia [17] in man. Inhaled DE also promotes atherosclerosis in mice [10,18-20]. Importantly, the procoagulant changes and impairment of vascular function induced by $\mathrm{DE}$ can be prevented by filtration [21,22], consistent with the hypothesis that the particulate component of $\mathrm{DE}$ drives the adverse cardiovascular effects (reviewed in [23]). To date, no investigation has directly determined the effect of diesel exhaust particulate (DEP) on the

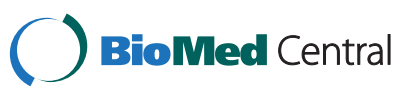


development of atherosclerotic lesions. We, therefore, addressed the hypothesis that exposure to DEP would increase lesion size and complexity in a murine model of atherosclerosis, and that this would be mediated by inflammation, endothelial dysfunction and oxidative stress.

\section{Results}

Instillation and pulmonary inflammation

Pulmonary instillation of DEP was chosen as the exposure method; to administer only the particulate components of diesel exhaust, to ensure the complete delivery of the dose to the lungs, and establish this model as a basis for future experiments looking at the effects of fractionated DEP. Instillation was well tolerated, with no mortality and no effect on body weight (Additional file 1: Figure S1). Lungs of DEP-instilled mice showed fibrotic thickening of the alveolar septae and cuffing of alveolar blood vessels (Figure 1a,b). Particulate was visible deep in the airways, largely within alveolar macrophages. Instillation of DEP produced similar increases in the total cell count in bronchoalveolar lavage fluid (BALF) from atherosclerosis-prone apoliprotein $\mathrm{E}$ knockout $\left(\mathrm{ApoE}^{-/-}\right)$ mice to that from wild-type (C57bl6) mice $(P<0.03$, unpaired $t$-test; $\mathrm{n}=7-9$; Figure $1 \mathrm{c})$. Macrophages were the predominant cell type in BALF (Figure 1d), although DEP also increased the number of neutrophils $(P<0.011)$ but not lymphocytes $(P>0.23)$ in both strains $(\mathrm{n}=7-9$ for all). DEP had no effect on interleukin-6 (IL-6; $P>0.13 ; \mathrm{n}=4-6$ for all), tumour necrosis factor alpha (TNF $\alpha ; P>0.25$; $\mathrm{n}=4-5$ for C57bl6, $\mathrm{n}=6-7$ for $\mathrm{ApoE}^{-/-}$) or monocyte chemotactic protein-1 (MCP-1; CCL2/JE; P > 0.23; $\mathrm{n}=4-5$ for all) levels in BALF (Additional file 1: Table S2).

\section{Distribution and size of atherosclerotic plaques}

Aortae from C57bl6 mice exhibited little Sudan IV staining in either the saline- or DEP-instilled groups. In saline-treated $\mathrm{ApoE}^{-1-}$ mice, lipid-rich lesions were visible on the surface of the thoracic aorta largely confined to the aortic arch (Figure 2a). Lipid incorporation was greater in DEP- than saline-instilled $\mathrm{ApoE}^{-/-}$mice $(P=0.046, \mathrm{n}=6-7$; Figure $2 \mathrm{~b})$.

The brachiocephalic artery, which develops complex atherosclerotic plaques, was chosen for histological analysis [24]. No lesions were evident in C57/bl6 mice (saline, $\mathrm{n}=3$; DEP, $\mathrm{n}=5$ ). In contrast, $\mathrm{ApoE}^{-1-}$ mice developed large lesions throughout the length of the brachiocephalic artery, particularly in the $400 \mu \mathrm{m}$ proximal to the bifurcation of the aortic arch (Figure 2c). Mean plaque size was markedly increased $(P=0.017)$ in DEPtreated $\mathrm{ApoE}^{-/-}$mice $(59 \pm 10 \%, \mathrm{n}=7)$ compared with controls $(32 \pm 7 \%, \mathrm{n}=9$; Figure 2d). This increase was seen using several different measures of lesion size (Additional file 1: Table S3). The size of atherosclerotic lesions was associated with levels of pulmonary inflammation (BALF total cell count) on the day of necropsy $(P=0.004, \mathrm{n}=16$; Figure 2e).
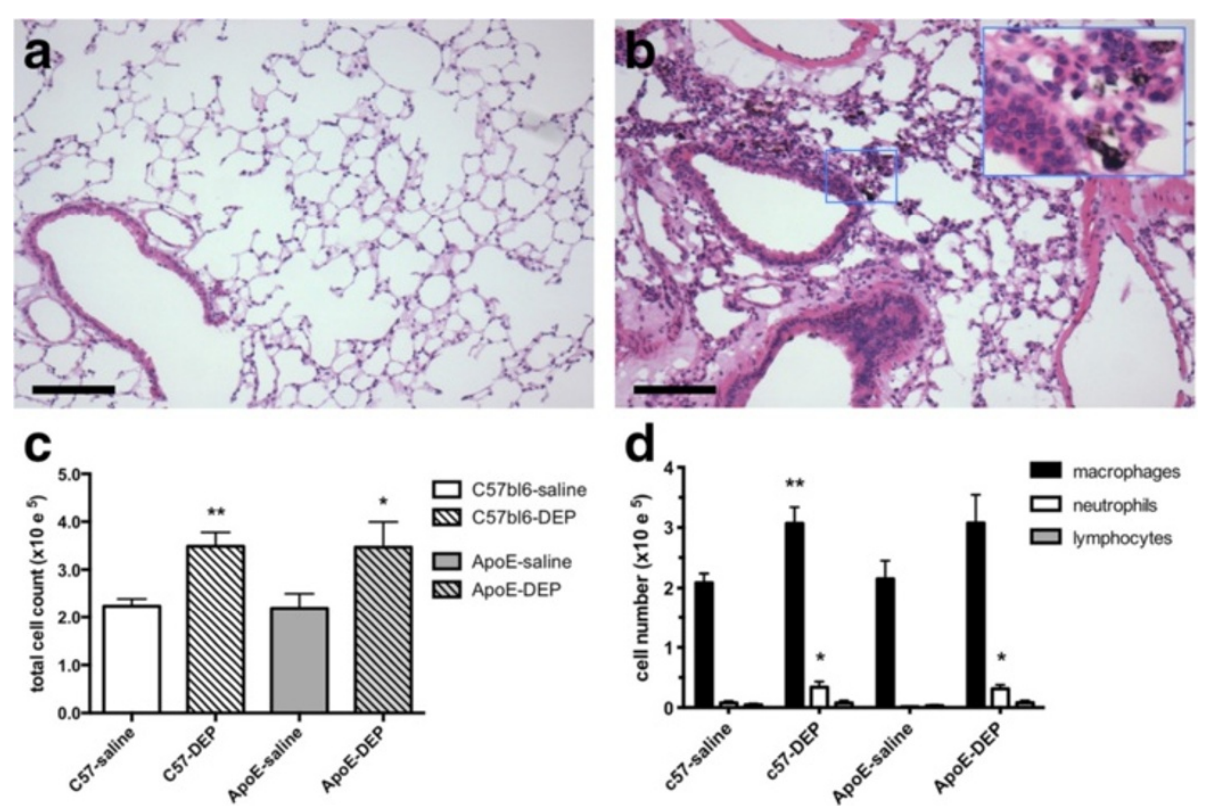

Figure 1 Instillation of DEP induces pulmonary inflammation and alveolar remodelling. Representative lung sections from (a) saline-instilled and (b) DEP-instilled $\mathrm{ApoE}^{-/-}$mice showing airway fibrosis and cuffing of pulmonary blood vessels. Inset: High power image showing particle-laden macrophages deep within the airspaces. Scale bars $=100 \mu \mathrm{m}$. (c) Total cell counts in BALF. (d) Cell differentials in BALF. Mean \pm S.E.M. ( $n=7-9$ for all) ${ }^{*} P<0.05,{ }^{* *} P<0.01$, unpaired t- test comparing DEP with saline control in same animal type. ApoE ${ }^{-1-}$ were fed Western diet for 8 weeks, whereas wild-type mice were fed normal chow. 


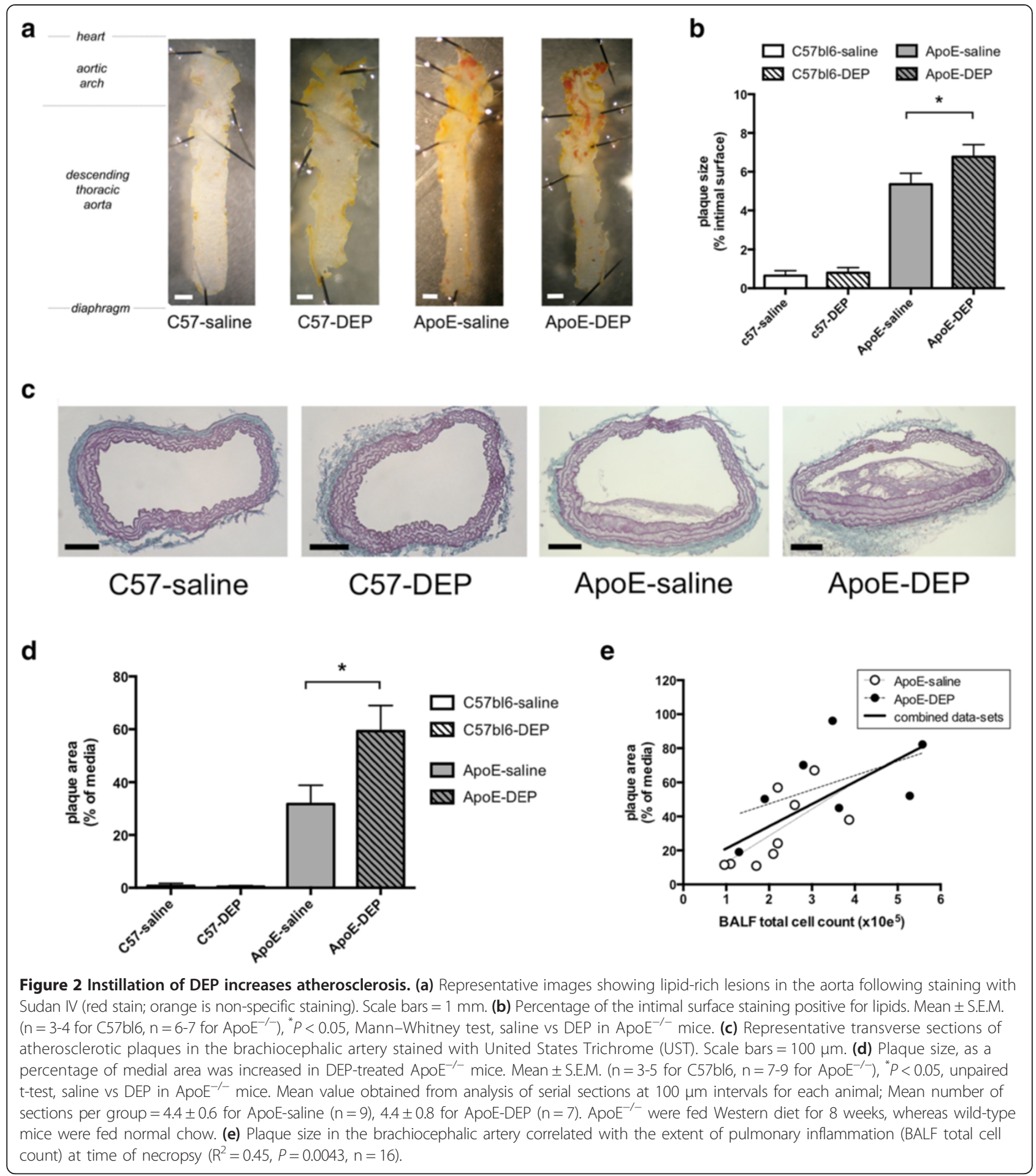

\section{Plaque composition and structure}

Plaque composition was studied in detail to provide insight into the potential ability of DEP to promote plaque instability. ApoE ${ }^{-/-}$mice developed complex atherosclerotic lesions with variable proportions of smooth muscle cells, foam cells, lipid, cholesterol crystals and fibrous tissue (Figure 3). Exposure to DEP had little effect on lesion composition ( $n=5-6 /$ group; Additional file 1: Figure S2). Quantification of foam cells (MAC-2-positive), lipid cavities, smooth muscle cells and collagen (Figure 3a-d) 

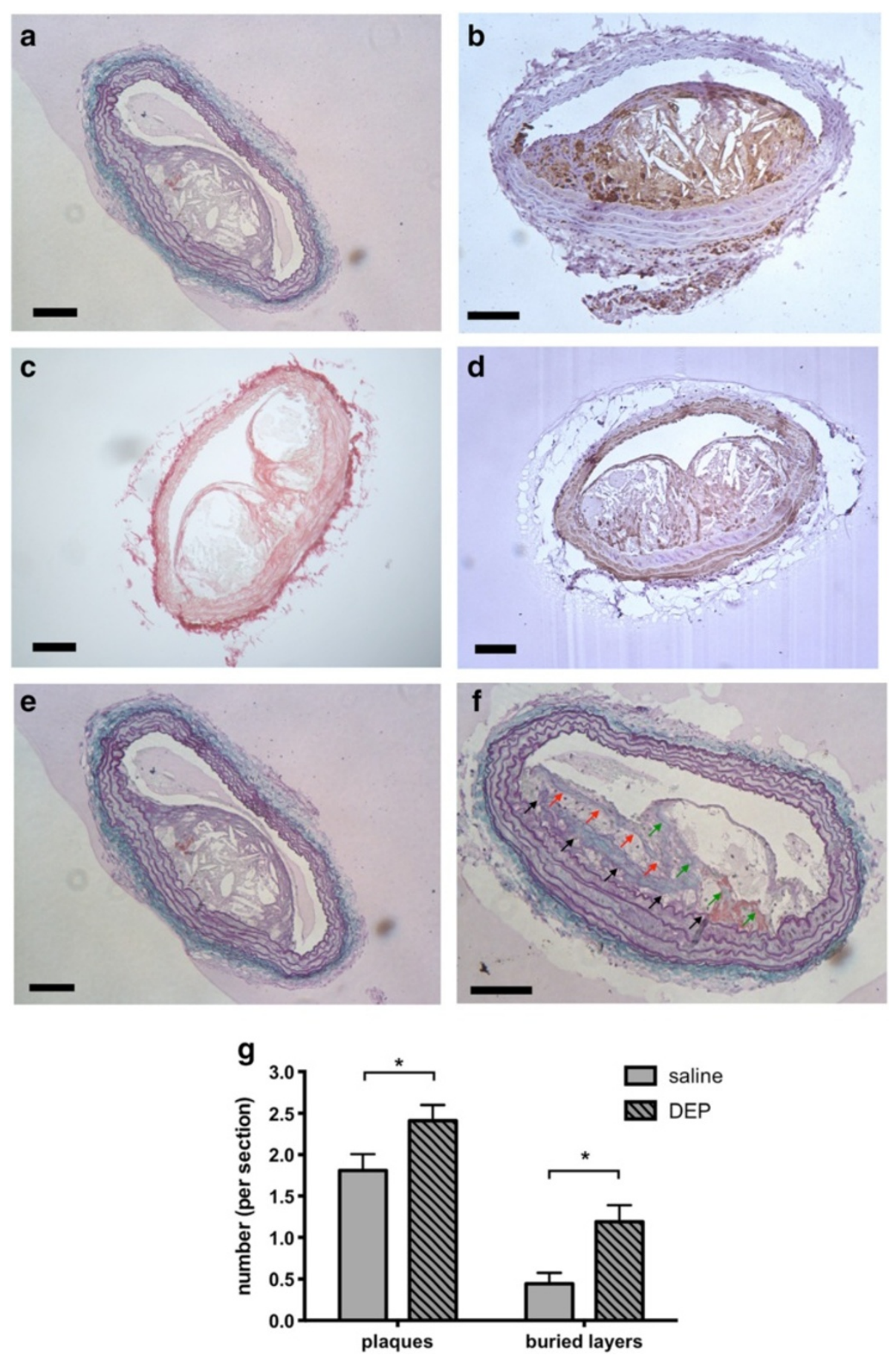

Figure 3 Assessment of plaque composition and structure. Representative brachiocephalic plaque sections showing (a) lipid cavities: plaque regions showing absence of all components of UST stain, (b) inflammatory cells: MAC2 immunohistochemistry (brown), (c) collagen: picrosirius red (red stain), (d) smooth muscle: SMA immunohistochemistry (brown). Scale bar $=100 \mu \mathrm{m}$. (e) Example of a large atherosclerotic plaque from a saline-treated $\mathrm{ApoE}^{-/-}$mouse, showing only a single plaque per section and no buried fibrous layers. (f) Example of three buried fibrous layers in a plaque (black, green and red arrows mark each fibrous layer) taken from a DEP-treated ApoE ${ }^{-/-}$mouse. UST staining, scale bar $=100 \mu \mathrm{m}$. (g) DEP instillation increased the average number of distinct plaques within each cross-section of lesion and the number of buried fibrous layers per section. Mean \pm S.E.M. Values obtained from analysis of serial sections at $100 \mu \mathrm{m}$ intervals for each animal; Mean number of sections per group $=4.4 \pm 0.7$ for ApoE-saline $(n=8), 4.4 \pm 0.8$ for ApoE-DEP $(n=7)$, ${ }^{*} P<0.05$, Mann-Whitney test comparing saline with DEP. All images shown are from arteries from DEP-instilled ApoE ${ }^{-/-}$mice, except panel 3 e, taken from saline-treated $\mathrm{ApoE}^{-/-}$mouse. 
showed no differences between saline- and DEP-treated ApoE $^{-/-}$mice ( $n=7-9 /$ group; Additional file 1: Figure S2). Similarly, no differences were detected in the levels of matrix metalloproteinases (MMP-2 and MMP-9; saline $\mathrm{n}=9$, DEP $\mathrm{n}=4$; Additional file 1: Figure S3) or fibrin/ fibrinogen (Additional file 1: Figure S4) in the plaques of DEP-treated mice ( $n=5-6 /$ group for all). However, DEP-treated animals had a greater number of distinct plaques per section of lesion ( $2.4 \pm 0.2$ plaques) compared with saline-treated controls $(1.8 \pm 0.2$ plaques; $P=0.022$, $\mathrm{n}=7-8$, Figure $3 \mathrm{e}-\mathrm{g})$. DEP also trebled the frequency of buried fibrous layers per section of lesion (1.2 \pm 0.2 vs $0.4 \pm 0.1 ; P=0.013, \mathrm{n}=7$-8; Figure $3 \mathrm{e}-\mathrm{g}$ ).

\section{Blood lipids, C-reactive protein and fibrinogen}

Serum cholesterol concentrations were increased in $\mathrm{ApoE}^{-1-}$ mice fed a Western diet $(20.1 \pm 0.7 \mathrm{mM})$ compared to C57bl6 mice fed standard chow $(1.3 \pm 1.5 \mathrm{mM}$; $\mathrm{n}=16$, combined saline and DEP, for both genotypes; $\mathrm{P}<0.001$, Figure 4a) whereas serum triglyceride concentrations were similar in both $\mathrm{ApoE}^{-/-}(0.34 \pm 0.03 \mathrm{mM})$ and C57bl6 mice $(0.36 \pm 0.02 \mathrm{mM} ; \mathrm{n}=16$, combined saline and DEP, for both genotypes; Figure $4 \mathrm{~b}$ ). Both variables were unaffected by DEP instillation. Similarly, serum C-reactive protein (CRP) and plasma fibrinogen concentrations were unaffected by DEP instillation (both $P>0.05 ; \mathrm{n}=8$ for all; Figure $4 \mathrm{c}, \mathrm{d}$; Additional file 1 : Table S2). Total and active tissue plasminogen activator (t-PA) levels were below the limit of detection $(n=7-8$ for all; Additional file 1: Table S2).

\section{Vascular function}

To determine whether DEP-instillation caused endothelial dysfunction, aortic rings were isolated for functional analysis. Phenylephrine caused an identical concentrationdependent contraction in $\mathrm{C} 57 \mathrm{bl} 6$ and $\mathrm{ApoE}^{-/-}$mice and was unaltered by DEP instillation $(P>0.24$, DEP vs saline; $n=6-7$; Figure 5a). Relaxations to the endotheliumdependent vasodilator, acetylcholine, or the endotheliumindependent nitric oxide (NO) donor, sodium nitroprusside (SNP), were unaffected by DEP-instillation in C57bl6 and ApoE $^{-/-}$mice $(P>0.29 ; n=4-5$ for all; Figure 5b,c). Similar responses to relaxants were seen if the arteries were precontracted with noradrenaline rather than phenylephrine ( $\mathrm{n}=3-7$; Additional file 1: Figure S5).
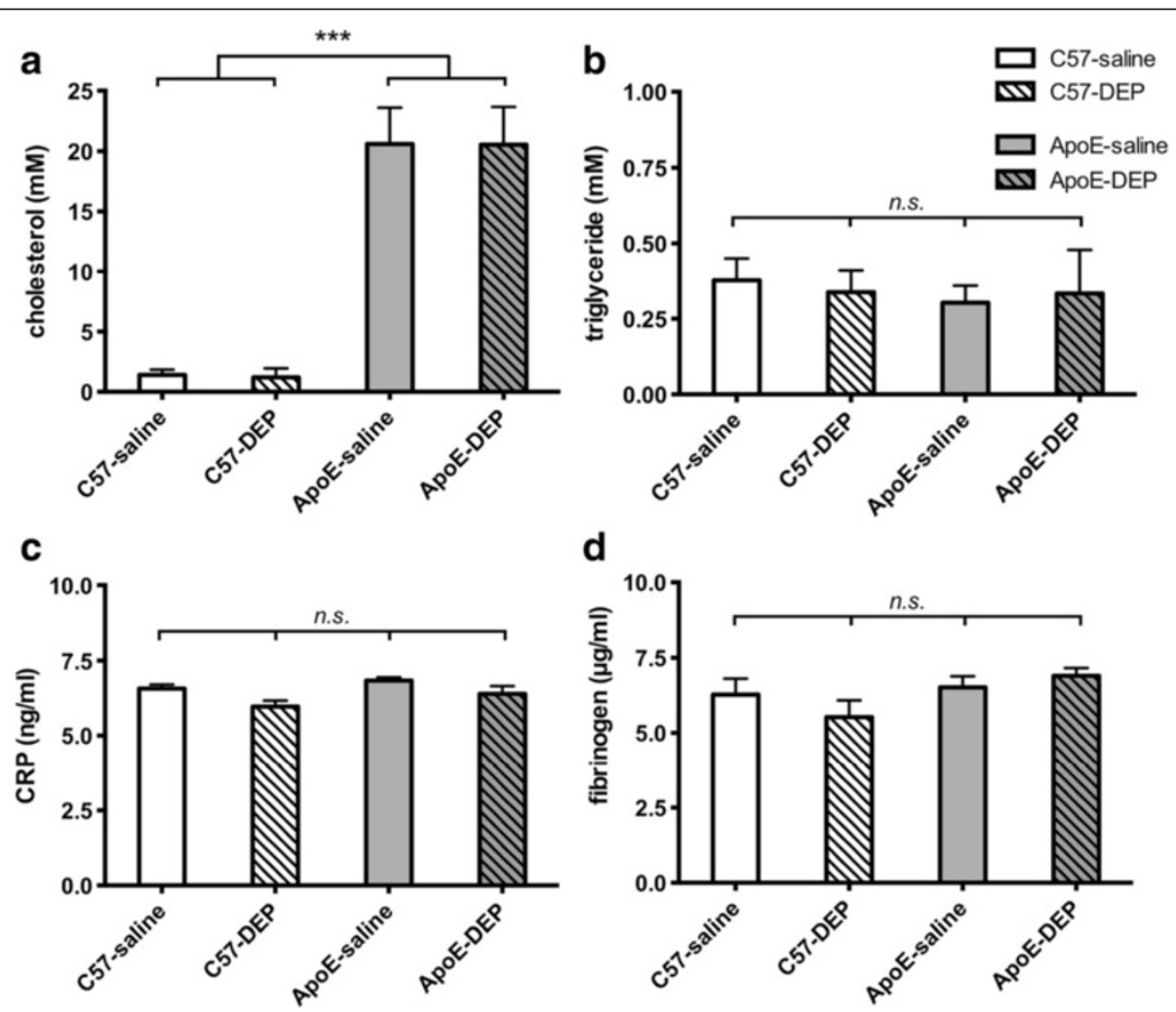

Figure 4 DEP instillation did not alter lipid or markers of systemic inflammation and coagulation within the blood. (a) Serum cholesterol $(n=10)$, (b) serum triglyceride $(n=10)$, (c) serum CRP $(n=8)$ and $(\mathbf{d})$ plasma fibrinogen $(n=8)$ levels. Mean \pm S.E.M. ${ }^{* * *} P<0.001$, unpaired t-test of C57bl6 vs ApoE; ${ }^{\text {ns }} P>0.05$, Bonferroni post-hoc tests, following one-way ANOVA. ApoE ${ }^{-/-}$were fed Western diet for 8 weeks, whereas wild-type mice were fed normal chow. 


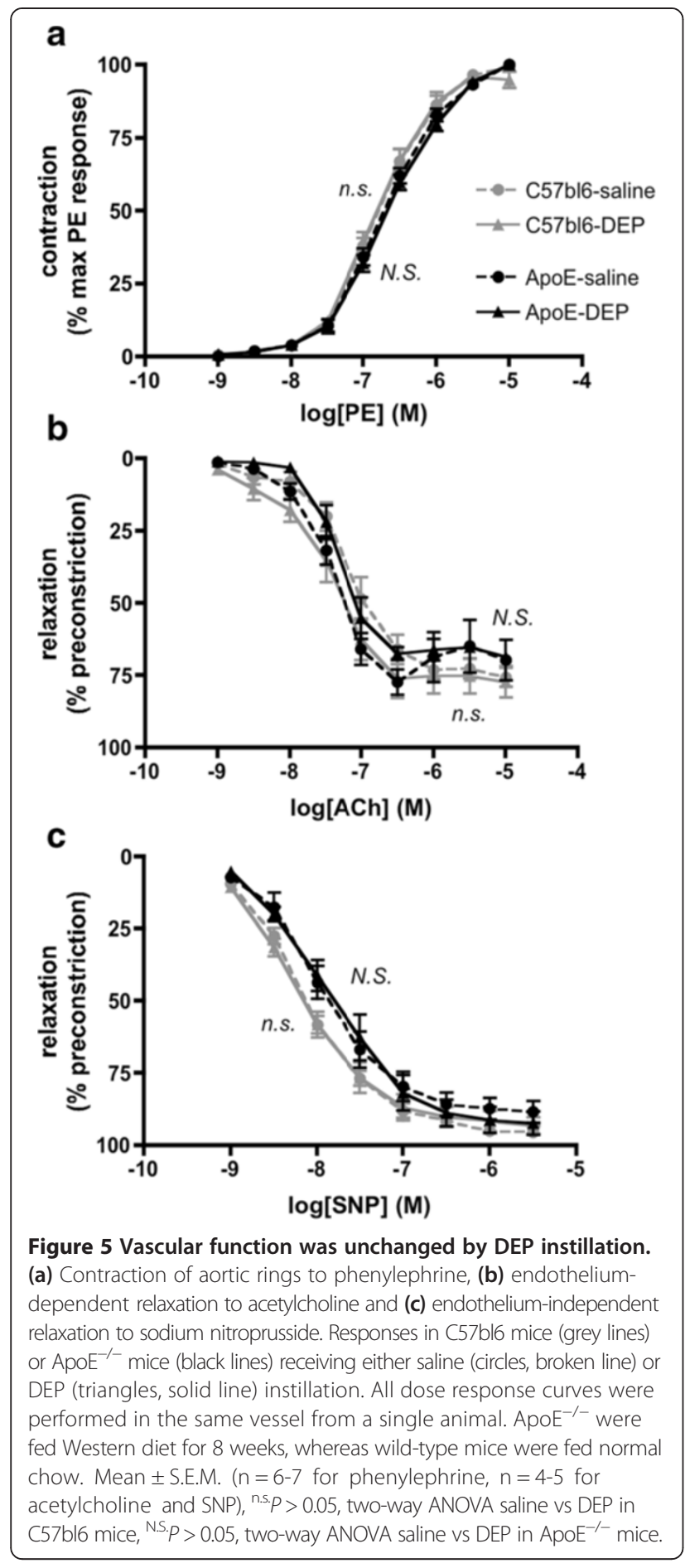

\section{Hepatic antioxidant expression}

Expression of antioxidants in liver was used to as an indicator of a response to a systemic oxidative stress. Instillation of DEP increased NF-E2-related factor-2 (Nrf2) expression in C57bl6 mice $(P<0.01 ; \mathrm{n}=5$ for all; Figure 6). Exposure to DEP induced an increase in gene expression of Nrf2 $(P=0.023 ; \mathrm{n}=5$ for all), NAD $(\mathrm{P}) \mathrm{H}$ quinone oxidoreductase 1 (NQO1; $P=0.034 ; \mathrm{n}=7$ for $\mathrm{C} 57 \mathrm{bl6}$

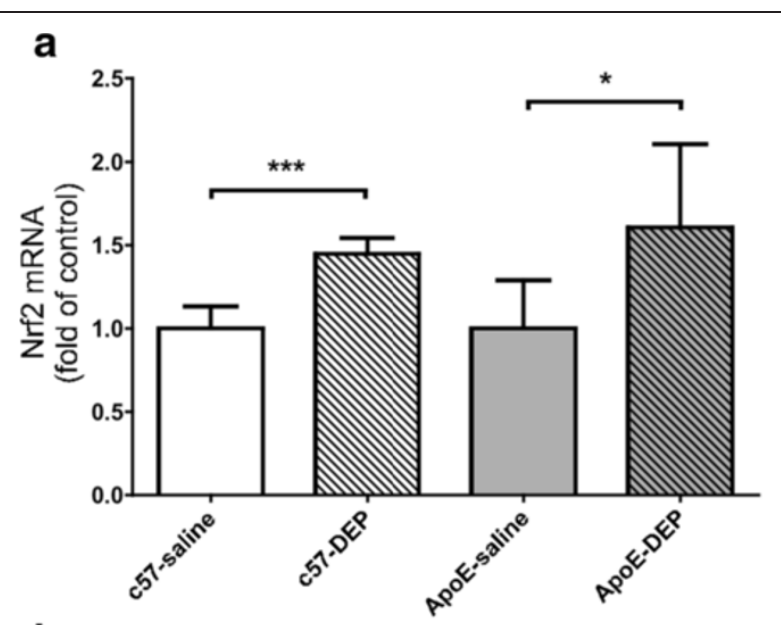

b
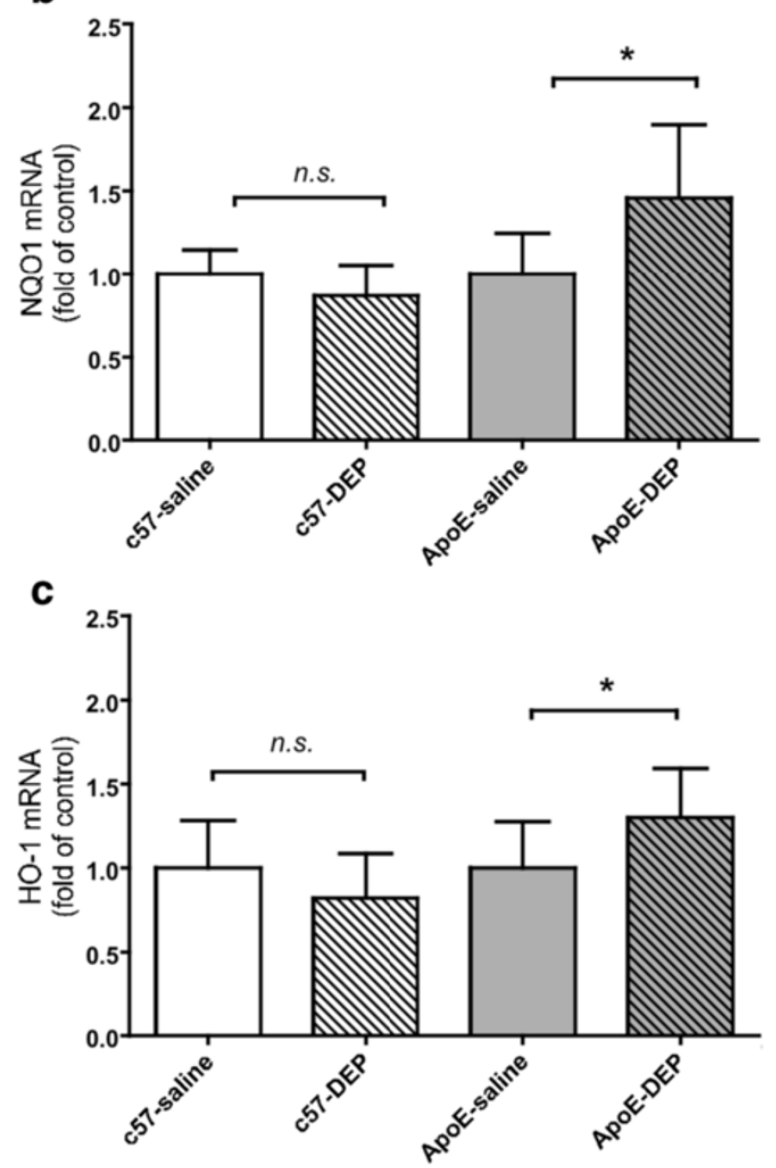

Figure 6 Instillation of DEP increased expression of antioxidant genes in the liver, particularly in $\mathrm{ApoE}^{-/-}$mice. (a) NF-E2-related factor-2 (Nrf2), (b) NAD(P)H-quinone oxidoreductase-1 (NQO1) and (c) hemeoxygenase-1 (HO-1). Effect of DEP shown as fold-increase in the expression in saline-treated mice. Mean \pm S.E.M. $(n=5-8),{ }^{n .5} . P>0.05$, ${ }^{*} P<0.05,{ }^{* *} P<0.001$, unpaired t-test comparing saline vs DEP. ApoE ${ }^{-/}$ were fed Western diet for 8 weeks, whereas wild-type mice were fed normal chow. 
groups, $\mathrm{n}=5$ for $\mathrm{ApoE}^{-/-}$groups) and hemeoxygenase-1 (HO-1; $P=0.027 ; \mathrm{n}=8$ for all) in $\mathrm{ApoE}^{-/-}$mice (Figure 6).

\section{Discussion}

We have here demonstrated that, in the murine apolipoprotein E deficiency model, instillation of DEP increased lesion size, produced more lesions per vessel and generated more buried fibrous caps. The proatherosclerotic effect was concomitant with pulmonary inflammation and systemic oxidative stress. We conclude that the particulate components of DE accelerate plaque development and are associated with a more complex plaque phenotype. The processes involved may contribute to the association between exposure to urban air pollution, atherosclerosis and acute myocardial infarction in man.

The influence of DEP was assessed using a recognised model of atherosclerosis at a period of extensive plaque expansion and remodelling [25,26]. Serial sections of artery were used to provide a surrogate marker of plaque volume and a sensitive approach to quantifying changes in plaque burden. We found that four weeks of repeated DEP exposure caused an almost doubling of plaque size from $32 \%$ to $59 \%$. The 4 -week exposure to DEP was consistent with pre-clinical investigations using concentrated ambient particles (CAPs) [8,9,27-30], whole DE $[11,19]$ and, to a lesser extent, non-carbon nanoparticles [31]. These previous studies have been performed in several different animal models $\left(\mathrm{ApoE}^{-/-}\right.$mice, low density lipoprotein receptor Apo E double knockout mice and Watanabe heritable hyperlipidaemic rabbits) using either inhalation $[8,10,11,19,30]$ or instillation $[27,29,31]$. The present study is the first to assess whether direct exposure to DEP increases atherosclerosis.

The marked increases in plaque size with DEP instillation are striking given the short duration of the exposure period. In the present study, long-term exposure has been emulated by administration of higher doses of particles over a shorter length of time. The instillation technique has been well validated [32-36] and the dose employed is similar to that of other studies using repeated instillations $[37,38]$, and below those commonly used for single instillation exposures. While we cannot rule out that a proportion of the particulate administered deposits in the upper airways, studies have shown that the aspiration instillation technique to provide excellent delivery and dispersity of particulate throughout the alveoli $[39,40]$. The MPPD particle deposition model [41] estimates that the average 24-h instilled dose used here (assuming all DEP reaches the alveoli) is approximately 40-fold higher than the comparable alveolar deposition from a 24-h inhalation of $100 \mu \mathrm{g} / \mathrm{m}^{3}$ in man (adjusted for mice). It is important to highlight that these calculations are based on inhalation of particles with a primary particle diameter of that of diesel exhaust $(\sim 60 \mathrm{~nm})$, whereas, urban levels of air pollution will contain a wide range of particulate sizes of which only a lower proportion of the larger particulates will penetrate past the tracheobronchial regions. Nevertheless, it is estimated that $20 \%(6-41 \%$; $[42,43])$ of the mass of $\mathrm{PM}_{2.5}$ is in the ultrafine range, and concentrations frequently reach $100 \mu \mathrm{g} / \mathrm{m}^{3}$ (a high percentage of which will originate from vehicle exhaust) for sustained periods in heavily polluted cities in both developed and developing nations. Furthermore, the airborne mass concentration of $100 \mu \mathrm{g} / \mathrm{m}^{3}$ represents a moderate/high PM levels over a 24-h period and does not take into account peaks in PM levels that regularly occur in cities, or the increased PM deposition produced by exercise such as brisk walking or cycling in urban environments. In comparison to a long-term continuous inhalation, the instillation regimen will unavoidably induce intermittent very high doses and dose-rate interspersed with long periods of non-exposure [44]. Nevertheless, the similarity of the current results with that of DE inhalation in $\mathrm{ApoE}^{-/-}$mice $[10,11,19,20,45]$ supports the contention that the biological pathways identified using the instillation protocol are both relevant and important. While a role for the gaseous component of DE cannot be excluded, our results suggest that the particulate component of $\mathrm{DE}$ alone is sufficient to enhance plaque formation. It is possible that the gaseous constituents could drive other responses leading to altered plaque composition [10] which we did not see in our study. The large magnitude of the pro-atherosclerotic effect of DEP will allow us to use this model in the future to explore which attributes and constituents of DEP (e.g. transition metals, polyaromatic hydrocarbons and quinones), and urban PM in general, are responsible for these effects.

Transient exposure to road-traffic has been linked to acute coronary events [46] and several pre-clinical investigations have suggested that exposure to atmospheric pollution increases markers of lesion vulnerability $[8,10,11,27,29]$. Urban PM $[8,27,30,47,48]$, whole DE $[11,19,20]$ or the gaseous components of DE [10], increase lipid content and inflammatory cells in plaques and the underlying vessel wall. Our results indicated that lipid and inflammatory cells increased in lesions from DEP-instilled mice, but only in proportion to lesion size.

While there was no change in the proportion of individual plaque constituents, or other typical markers associated with plaque vulnerability (e.g. MMPs), the complexity of the lesions in DEP-instilled mice was increased, with more lesions per section and more buried caps within lesions compared with controls. The results are similar to that previously observed in $\mathrm{ApoE}^{-/-}$mice exposed to whole DE by inhalation: an effect that was prevented by addition of a cerium additive to the diesel fuel that decreased the number of particles in the exhaust [20]. It has been suggested that the presence of 
buried fibrous layers in the brachiocephalic artery are signs of plaque erosion or a previous plaque rupture $[49,50]$. The question as to whether buried fibrous layers are evidence of plaque rupture, or is merely a feature of the on-going development of a single plaque, remains a subject of debate [25,51]. Atherosclerotic lesions in $\mathrm{ApoE}^{-/-}$mice do not rupture catastrophically, but similar changes in human lesions would be associated with increased plaque vulnerability $[48,52]$. Thus, these findings would suggest that the ability of DEP to increase plaque size and complexity are likely to be an important contributor to the cardiovascular manifestations of urban air pollution in man.

Previous investigations have suggested that increased atherosclerosis following exposure to DE or CAPs may be due to increased systemic inflammation [11,27-29], vascular dysfunction $[8,19,30]$, or increased oxidative stress [9-11,30]. In the current investigation, DEP did not increase circulating concentrations of plasma lipids or plaque lipid content, therefore, the exacerbation of lesion formation cannot be attributed to altered lipid handling.

It has been hypothesised that inhaled particles exert their cardiovascular effects indirectly through the passage of inflammatory mediators from the lung to the systemic circulation [53]. DEP caused a clear lung inflammation characterised by infiltration of macrophages and neutrophils into the airways. Interestingly, there was an association with levels of lung inflammation and the size of atherosclerotic plaques. Other studies have failed to find an association between the ability of nanoparticles to induce pulmonary inflammation and their actions on a range of cardiovascular end-points (reviewed in [54]). Concentrations of acute phase proteins (CRP) in the blood were unchanged by DEP exposure. Although we cannot exclude transient surges in cytokines in response to the particulate, or the involvement of other cytokines (e.g. tumour necrosis factor alpha, interleukins, serum amyloid A3), we have not found consistent changes in any blood cytokine at either early $(2 \mathrm{~h})$ or late $(24 \mathrm{~h})$ timepoints after DE exposure in man $[14,15,55]$. Future studies will address these possibilities in more detail. Additionally, in the present study DEP did not change the inflammatory cell content of atherosclerotic plaques, a finding similar to that after 40 days inhalation of CAPs [9]. Overall, while inflammatory pathways are likely to contribute to the cardiovascular effects of DEP, neither pulmonary nor systemic inflammation alone can account for the atherogenic actions of DEP.

Repeated instillation of DEP was not associated evidence of vascular dysfunction. Previous investigations have reported increased $[8,19]$ or reduced [30] vascular contractility accompanying atherosclerosis following pollutant exposure. There have also been contradictory indications of normal [30] or impaired [8] acetylcholine-mediated relaxation. However, in the latter, the magnitude of the impairment was small and followed prolonged ( $>10$ weeks) exposure and high-fat feeding. Alternatively, vasomotor impairment may be restricted to resistance arteries [56] and not the large conductance arteries where atherogenesis takes place. Our results suggest that vascular dysfunction is not required for DEP-induced acceleration of atherosclerosis.

The hepatic up-regulation of several protective antioxidant genes in response to DEP suggests a counterregulatory response to the systemic pro-oxidative effects of DEP. We have previously shown that the Nfr2 pathway is also upregulated in systemic tissues in response to inhalation of ultrafine urban PM in $\mathrm{ApoE}^{-/-}$mice [9] and whole diesel exhausts [45]. Interestingly, up-regulation of Nrf2 could trigger vascular proatherogenic effects as we have recently reported that systemic Nrf2 deletion inhibits rather than promotes atherosclerotic lesion formation in the aorta of ApoE null mice [57]. DEP itself can generate free radicals in solution [58], and oxidative stress is one of the most consistently proposed links between the pulmonary and systemic effects of particulate exposure [59]. Vehicle exhaust promotes lipid peroxidation in plasma lipoproteins and systemic tissues [60], consistent with recent studies where DE led to increased plasma levels of 8-isoprostanes, 12-HETEs, 13-HODEs, the development of dysfunctional prooxidative and proinflammatory high density lipoprotein (HDL) [45], and increased isoprostanes in urine [11]. Although we did not evaluate the status of lipid peroxidation in our study, we suggest that the systemic pro-oxidative effects of the particulates in DE could drive a significant portion of the proatherosclerotic actions of urban PM. Interestingly, antioxidant upregulation was especially notable in $\mathrm{ApoE}^{-1-}$ mice compared to wild-type mice. This observation adds to the growing evidence that animals/individuals with pre-existing vascular disease (or their risk factors), or diseases with associated cardiovascular complications (e.g. diabetes), may be particularly susceptible to the effects of air pollution $[1,7,61,62]$.

\section{Conclusions}

Exposure of the particulate constituents of diesel exhaust increases both the size and complexity of atherosclerotic plaques in vivo, and may therefore increase the susceptibility of plaques to rupture. The increased atherogenesis was not directly related to raised levels of systemic inflammation, changes in lipid handling or endothelial dysfunction, but was associated with pulmonary inflammation and systemic changes in antioxidant expression. Similar changes in man would be predicted to increase plaque vulnerability and rupture, helping to explain the associations between urban air pollution and acute myocardial infarction. These findings provide support for the 
implementation of strategies to remove vehicle-derived particulate emissions as a means to reduce the detrimental health effects of air pollution.

\section{Methods}

Detailed Methods in Additional file 1.

\section{Animals, instillations and necropsy}

All experiments were performed according to the Animals (Scientific Procedures) Act 1986 (UK Home Office). Adult male $\mathrm{ApoE}^{-/-}$mice $(\mathrm{N}=20)$ and the background strain (C57bl6 mice; $\mathrm{N}=16$ ) were purchased from Charles River (Margate, UK) aged 8-9 wks (20-25 g). C57bl6 mice were fed 8 weeks standard chow, whereas $\mathrm{ApoE}^{-/-}$mice received a high fat 'Western Diet' (21\% fat; Research Diets, New Brunswick, USA). This approach was used to allow a direct comparison of the effect of DEP on animals with no atherosclerosis with that of animals exhibiting large 'complex' atherosclerotic plaques, respectively.

For the final four weeks of feeding, mice underwent twice weekly instillation (oropharnyngeal aspiration) of $35 \mu \mathrm{g}$ DEP $(35 \mu \mathrm{L}$ of $1 \mathrm{mg} / \mathrm{mL}$; National Institute of Standards and Technology (NIST); SRM-2975; Gaithersburg, U.S.A.), to represent an average daily dose of $10 \mu \mathrm{g} / \mathrm{mouse}$ (see Discussion). This reference material is a commonly used source of DEP, allowing comparability with other researchers, and we have previously shown it has the capacity to generate superoxide free radicals in vitro, stimulate cultured macrophages and can directly impair arterial function $[58,63]$. The mean particle size of DEP in saline buffer prior to administration was $257 \pm 46 \mathrm{~nm}$ ( $n=6$; dynamic light scattering, Brookhaven PS90 Particle Size Analyser; data not shown). Animals were sacrificed 3-4 days after their last instillation and blood $(0.6-1 \mathrm{~mL})$ withdrawn from the heart. Lungs were lavaged with sterile saline $(3 \mathrm{x} 0.8 \mathrm{~mL})$ to collect bronchoalveolar lavage fluid (BALF), and the carotid arteries, brachiocephalic artery, aortic arch, thoracic aorta and liver biopsies collected.

\section{Measures of pulmonary inflammation}

BALF samples were centrifuged $\left(180 \mathrm{~g}, 5 \mathrm{~min}, 4^{\circ} \mathrm{C}\right)$ and the cell pellets combined, resuspended, stained with Diff-Quik (Raymond A Lamb, London, UK) and prepared into cytocentrifuge smears for differential cell counts. The inflammatory cytokines interleukin-6 (IL-6), tumour necrosis factor alpha (TNF- $\alpha$ ) and monocyte chemotactic protein-1 (MCP-1; CCL2/JE) were measured in the primary cell-free BALF by enzyme-linked immunosorbent assay (ELISA; R\&D Duoset Systems; Patricell Ltd, Nottingham, UK).

\section{Assessment of atherosclerosis}

The aortic arch and descending thoracic aorta were randomly selected from half of the mice from each treatment group. The artery was cut longitudinally and lipid-rich atherosclerotic plaques were stained en-face using Sudan IV.

Brachiocephalic arteries were fixed in formalin and histological sections were taken in triplicate at $100 \mu \mathrm{m}$ intervals, beginning at the first section of artery with a fully intact media. Sections were stained with United States Trichrome (UST). The cross-sectional area of the plaque was measured and standardised to the medial area. The medial wall was chosen for standardisation rather than luminal area, as vessels could not be perfusion-fixed in situ, as they were also required for assessment of vascular function by myography (see below). A single mean value of atherosclerotic burden for each animal was calculated from the plaque size from each complete serial section throughout the brachiocephalic artery.

Plaque composition was assessed by both semiquantitative scoring of fibrous matrix, foam cell and lipid content, and thickness of plaque cap, in UST-stained sections. Quantitative measurement of plaque constituents was performed using histology (collagen, fibrin) and immunohistochemistry (lipids, macrophages, smooth muscle cells, fibrinogen, metalloproteinases).

Plaque structure was assessed by counting distinct adjoining, or overlying, plaques within each section [20]. Additionally, the number of buried fibrous layers (defined as 'a length of fibrous/cellular matter that completely bisects a lipid-rich regions of two overlying plaque sections [24]) was counted in each section throughout the artery and a mean value obtained. Samples were randomised before assessment and all scores independently verified by a second blinded assessor. See Additional file 1 for full details on methods used to assess atherosclerosis.

\section{Measurement of blood lipids, C-reactive protein and fibrinogen}

Non-citrated blood was allowed to clot on ice ( $>2$ hours, $\left.4^{\circ} \mathrm{C}\right)$, centrifuged $(10,000 \mathrm{rpm}, 10 \mathrm{~min})$ and used for colormetric measurement of cholesterol and triglycerides (Microgenics, St Albans, UK), and C-reactive protein (CRP) by ELISA (Innovative Research kits; Patricell, Nottingham, UK). Citrated blood was centrifuged $(3,000 g, 15 \mathrm{~min})$ to collect platelet-poor plasma for measurement of fibrinogen (Innovative Research ELISA kits; Patricell, UK).

\section{Vascular function}

Segments (1-2 mm length) of the distal portion of the thoracic aorta were mounted in a multi-myograph system (610M; Danish Myo Technology, Aarhus, Denmark). Concentration-response curves were generated for phenylephrine (PE), the endothelium-dependent vasodilator, acetylcholine ( $\mathrm{ACh}$ ), and the endothelium-independent nitric oxide (NO) donor sodium nitroprusside (SNP). Only a single segment was used from each animal, and all dose 
response curves were performed in the same vessel. Drugs were washed out for $>30 \mathrm{~min}$, and prior dose response curves did not affect the responses to subsequent drugs.

\section{Expression of hepatic antioxidants}

The expression of tissue mRNA for hemeoxygenase-1 (HO-1), NAD(P)H-quinone oxidoreductase 1 (NQO1), catalase, and NF-E2-related factor-2 (Nrf2) were measured by quantitative real-time polymerase chain reaction [9].

\section{Statistical analysis}

Statistical comparisons were made using unpaired Student's $t$-test or analysis of variance (ANOVA) with Bonferroni post-hoc tests where appropriate. Kruskal-Wallis or MannWhitney tests were used for non-parametric or ordinal level data (1-5 scoring of plaque components). Two-sided $P<0.05$ was taken as statistically significant.

\section{Additional file}

Additional file 1: On-line supplementary information.

\section{Abbreviations}

ACh: Acetylcholine; ANOVA: Analysis of variance; $\mathrm{ApoE}^{-/-}$: Apolipoprotein E knockout; BALF: Bronchoalveolar lavage fluid; CAPs: Concentrated ambient particles; CRP: C-reactive protein; DE: Diesel exhaust; DEP: Diesel exhaust particulate; ELISA: Enzyme-linked immunosorbent assay; HO-1: Hemeoxygenase-1; IL-6: Interleukin-6; MCP-1: Monocyte chemotactic protein-1; MMP: Matrix metalloproteinase; NIST: National Institute of Standards and Technology; NQO1: NAD(P)H-quinone oxidoreductase 1; Nrf2: NF-E2-related factor-2; NO: Nitric oxide; PE: Phenylephrine; PM: Particulate matter; S.E.M.: Standard error of the mean; SMA: Smooth muscle actin; SNP: Sodium nitroprusside; TNF-a: Tumour necrosis factor alpha; UST: United States Trichrome.

\section{Competing interests}

The authors declare that they have no competing interests.

\section{Authors' contributions}

MRM designed the study, carried out the experimental work, carried out the statistical analysis and drafted the manuscript. SGM carried out the experimental work, and assisted with the data and image analysis. RD assisted with the particle instillations and pulmonary assays, and contributed to the drafting of the manuscript. AOL carried out the antioxidant expression work and analysis. JAA contributed to the interpretation of the data and helped draft the manuscript. CAS contributed to the drafting of the manuscript. NLM contributed to the drafting of the manuscript. KD participated in the design and interpretation of the study, and helped to draft the manuscript. DEN participated in the design and interpretation of the study, and helped to draft the manuscript. PWFH participated in the design and interpretation of the study, and helped to draft the manuscript. All authors have read and approved the final version of the manuscript.

\section{Acknowledgements}

We acknowledge the support of the British Heart Foundation Centre of Research Excellence (CORE) award.

\section{Sources of funding}

This work was funded by British Heart Foundation Programme (RG/10/009) and Project (PG/10/042/28388) Grants. AOL and JAA are funded by an Outstanding New Investigator in the Environmental Sciences Award from the National Institute of Environmental Health Sciences (RO1 ES016959). DEN is funded by the British Heart Foundation ( $\mathrm{CH} / 09 / 002)$.

\section{Author details}

${ }^{1}$ Centre for Cardiovascular Sciences, University of Edinburgh, 47 Little France Crescent, EH16 4TJ Edinburgh, Scotland, UK. ${ }^{2}$ Centre for Inflammation Research, University of Edinburgh, Edinburgh, Scotland, UK. ${ }^{3}$ Division of Cardiology, David Geffen School of Medicine at UCLA, Los Angeles, CA, USA.

Received: 30 August 2013 Accepted: 2 December 2013

Published: 11 December 2013

\section{References}

1. Brook RD, Rajagopalan S, Pope CA 3rd, Brook JR, Bhatnagar A, Diez-Roux AV, Holguin F, Hong Y, Luepker RV, Mittleman MA, et al: Particulate matter air pollution and cardiovascular disease: An update to the scientific statement from the American Heart Association. Circulation 2010, 121:2331-2378.

2. Dockery DW, Pope CA 3rd, Xu X, Spengler JD, Ware JH, Fay ME, Ferris BG Jr, Speizer FE: An association between air pollution and mortality in six U.S. cities. N Engl J Med 1993, 329:1753-1759.

3. Hoffmann B, Moebus S, Mohlenkamp S, Stang A, Lehmann N, Dragano N, Schmermund A, Memmesheimer M, Mann K, Erbel R, Jockel KH: Residential exposure to traffic is associated with coronary atherosclerosis. Circulation 2007, 116:489-496.

4. Kunzli N, Perez L, von Klot S, Baldassarre D, Bauer M, Basagana X, Breton C, Dratva J, Elosua R, de Faire U, et al: Investigating air pollution and atherosclerosis in humans: concepts and outlook. Prog Cardiovasc Dis 2011, 53:334-343.

5. Tonne C, Yanosky JD, Beevers S, Wilkinson P, Kelly FJ: PM mass concentration and PM oxidative potential in relation to carotid intima-media thickness. Epidemiology 2012, 23:486-494.

6. Adar SD, Sheppard L, Vedal S, Polak JF, Sampson PD, Diez Roux AV, Budoff M, Jacobs DR Jr, Barr RG, Watson K, Kaufman JD: Fine particulate air pollution and the progression of carotid intima-medial thickness: a prospective cohort study from the multi-ethnic study of atherosclerosis and air pollution. PLoS Med 2013, 10:e1001430.

7. Moller P, Mikkelsen L, Vesterdal LK, Folkmann JK, Forchhammer L, Roursgaard M, Danielsen PH, Loft S: Hazard identification of particulate matter on vasomotor dysfunction and progression of atherosclerosis. Crit Rev Toxicol 2011, 41:339-368.

8. Sun Q, Wang A, Jin X, Natanzon A, Duquaine D, Brook RD, Aguinaldo JG, Fayad ZA, Fuster $V_{\text {, Lippmann } M}$, et al: Long-term air pollution exposure and acceleration of atherosclerosis and vascular inflammation in an animal model. JAMA 2005, 294:3003-3010.

9. Araujo JA, Barajas B, Kleinman M, Wang X, Bennett BJ, Gong KW, Navab M, Harkema J, Sioutas C, Lusis AJ, Nel AE: Ambient particulate pollutants in the ultrafine range promote early atherosclerosis and systemic oxidative stress. Circ Res 2008, 102:589-596.

10. Campen MJ, Lund AK, Knuckles TL, Conklin DJ, Bishop B, Young D, Seilkop S, Seagrave J, Reed MD, McDonald JD: Inhaled diesel emissions alter atherosclerotic plaque composition in $\mathrm{ApoE}(-/-)$ mice. Toxicol App/ Pharmacol 2010, 242:310-317.

11. Bai N, Kido T, Suzuki H, Yang G, Kavanagh TJ, Kaufman JD, Rosenfeld ME, van Breemen C, Eeden SF: Changes in atherosclerotic plaques induced by inhalation of diesel exhaust. Atherosclerosis 2011, 216:299-306.

12. Peters A, Wichmann HE, Tuch T, Heinrich J, Heyder J: Respiratory effects are associated with the number of ultrafine particles. Am J Respir Crit Care Med 1997, 155:1376-1383.

13. MacNee W, Donaldson K: How can ultrafine particles be responsible for increased mortality? Monaldi Arch Chest Dis 2000, 55:135-139.

14. Mills NL, Tornqvist H, Robinson SD, Gonzalez M, Darnley K, MacNee W, Boon NA Donaldson K, Blomberg A, Sandstrom T, Newby DE: Diesel exhaust inhalation causes vascular dysfunction and impaired endogenous fibrinolysis. Circulation 2005, 112:3930-3936.

15. Tornqvist H, Mills NL, Gonzalez M, Miller MR, Robinson SD, Megson IL, Macnee W, Donaldson K, Soderberg S, Newby DE, et al: Persistent endothelial dysfunction in humans after diesel exhaust inhalation. Am J Respir Crit Care Med 2007, 176:395-400

16. Lucking AJ, Lundback M, Mills NL, Faratian D, Barath SL, Pourazar J, Cassee FR, Donaldson K, Boon NA, Badimon JJ, et al: Diesel exhaust inhalation increases thrombus formation in man. Eur Heart J 2008, 29:3043-3051.

17. Mills NL, Tornqvist H, Gonzalez MC, Vink E, Robinson SD, Soderberg S, Boon NA, Donaldson K, Sandstrom T, Blomberg A, Newby DE: Ischemic and thrombotic 
effects of dilute diesel-exhaust inhalation in men with coronary heart disease. N Engl J Med 2007, 357:1075-1082.

18. Bai N, Kido T, Kavanagh TJ, Kaufman JD, Rosenfeld ME, van Breemen C, van Eeden SF: Exposure to diesel exhaust up-regulates iNOS expression in ApoE knockout mice. Toxicol Appl Pharmacol 2011, 255:184-192.

19. Quan C, Sun Q, Lippmann M, Chen LC: Comparative effects of inhaled diesel exhaust and ambient fine particles on inflammation, atherosclerosis, and vascular dysfunction. Inhal Toxicol 2010, 22:738-753.

20. Cassee FR, Campbell A, Boere AJ, McLean SG, Duffin R, Krystek P, Gosens I, Miller MR: The biological effects of subacute inhalation of diesel exhaust following addition of cerium oxide nanoparticles in atherosclerosis-prone mice. Environ Res 2012, 115:1-10.

21. Lucking AJ, Lundback M, Barath SL, Mills NL, Sidhu MK, Langrish JP, Boon NA, Pourazar J, Badimon JJ, Gerlofs-Nijland ME, et al: Particle traps prevent adverse vascular and prothrombotic effects of diesel engine exhaust inhalation in men. Circulation 2011, 123:1721-1728.

22. Mills NL, Miller MR, Lucking AJ, Beveridge J, Flint L, Boere AJ, Fokkens PH, Boon NA, Sandstrom T, Blomberg A, et al: Combustion-derived nanoparticulate induces the adverse vascular effects of diesel exhaust inhalation. Eur Heart J 2011, 32:2660-2671.

23. Araujo JA: Particulate air pollution, systemic oxidative stress, inflammation, and atherosclerosis. Air Qual Atmos Health 2011, 4:79-93.

24. Rosenfeld ME, Polinsky P, Virmani R, Kauser K, Rubanyi G, Schwartz SM: Advanced atherosclerotic lesions in the innominate artery of the ApoE knockout mouse. Arterioscler Thromb Vasc Biol 2000, 20:2587-2592.

25. Jackson $\mathrm{CL}$ : Defining and defending murine models of plaque rupture. Arterioscler Thromb Vasc Biol 2007, 27:973-977.

26. Johnson J, Carson K, Williams H, Karanam S, Newby A, Angelini G, George S, Jackson C: Plaque rupture after short periods of fat feeding in the apolipoprotein E-knockout mouse: model characterization and effects of pravastatin treatment. Circulation 2005, 111:1422-1430.

27. Suwa T, Hogg JC, Quinlan KB, Ohgami A, Vincent R, van Eeden SF: Particulate air pollution induces progression of atherosclerosis. J Am Coll Cardiol 2002, 39:935-942.

28. Chen LC, Hwang JS: Effects of subchronic exposures to concentrated ambient particles (CAPs) in mice. IV. Characterization of acute and chronic effects of ambient air fine particulate matter exposures on heart-rate variability. Inhal Toxicol 2005, 17:209-216.

29. Yatera K, Hsieh J, Hogg JC, Tranfield E, Suzuki H, Shih CH, Behzad AR Vincent $R$, van Eeden SF: Particulate matter air pollution exposure promotes recruitment of monocytes into atherosclerotic plaques. Am J Physiol Heart Circ Physiol 2008, 294:H944-H953.

30. Ying Z, Kampfrath T, Thurston G, Farrar B, Lippmann M, Wang A, Sun Q, Chen LC, Rajagopalan S: Ambient particulates alter vascular function through induction of reactive oxygen and nitrogen species. Toxicol $\mathrm{SCl}$ 2009, 111:80-88

31. Mikkelsen L, Sheykhzade M, Jensen KA, Saber AT, Jacobsen NR, Vogel U, Wallin H, Loft S, Moller P: Modest effect on plaque progression and vasodilatory function in atherosclerosis-prone mice exposed to nanosized TiO(2). Part Fibre Toxicol 2011, 8:32.

32. Miyabara $Y$, Ichinose $T$, Takano $H$, Sagai M: Diesel exhaust inhalation enhances airway hyperresponsiveness in mice. Int Arch Allergy Immunol 1998, 116:124-131.

33. Miyabara $Y$, Takano H, Ichinose T, Lim HB, Sagai M: Diesel exhaust enhances allergic airway inflammation and hyperresponsiveness in mice. Am J Respir Crit Care Med 1998, 157:1138-1144.

34. Takano H, Yoshikawa T, Ichinose T, Miyabara Y, Imaoka K, Sagai M: Diesel exhaust particles enhance antigen-induced airway inflammation and local cytokine expression in mice. Am J Respir Crit Care Med 1997, 156:36-42.

35. Henderson RF, Driscoll KE, Harkema JR, Lindenschmidt RC, Chang IY, Maples KR, Barr EB: A comparison of the inflammatory response of the lung to inhaled versus instilled particles in F344 rats. Fundam Appl Toxicol 1995, 24:183-197.

36. Driscoll KE, Costa DL, Hatch G, Henderson R, Oberdorster G, Salem H, Schlesinger RB: Intratracheal instillation as an exposure technique for the evaluation of respiratory tract toxicity: uses and limitations. Toxico/ $\mathrm{SCi}$ 2000, 55:24-35.

37. Emmerechts J, Alfaro-Moreno E, Vanaudenaerde BM, Nemery B, Hoylaerts MF: Short-term exposure to particulate matter induces arterial but not venous thrombosis in healthy mice. J Thromb Haemost 2010, 8:2651-2661.

38. Inoue $K$, Takano H, Yanagisawa R, Ichinose T, Shimada A, Yoshikawa T: Pulmonary exposure to diesel exhaust particles induces airway inflammation and cytokine expression in NC/Nga mice. Arch Toxicol 2005, 79:595-599.

39. Lakatos HF, Burgess HA, Thatcher TH, Redonnet MR, Hernady E, Williams JP, Sime PJ: Oropharyngeal aspiration of a silica suspension produces a superior model of silicosis in the mouse when compared to intratracheal instillation. Exp Lung Res 2006, 32:181-199.

40. Rao GV, Tinkle S, Weissman DN, Antonini JM, Kashon ML, Salmen R, Battelli LA, Willard PA, Hoover MD, Hubbs AF: Efficacy of a technique for exposing the mouse lung to particles aspirated from the pharynx. J Toxicol Environ Health A 2003, 66:1441-1452.

41. Anjilvel S, Asgharian B: A multiple-path model of particle deposition in the rat lung. Fundam Appl Toxicol 1995, 28:41-50.

42. Langrish JP, Li J, Wang S, Lee MM, Barnes GD, Lei GG, Miller MR, Cassee FR, Boon NA, Donaldson K, et al: Reducing particulate air pollution exposure in patients with coronary heart disease improved cardiovascular health Environ Health Perspect 2012, 120:367-372.

43. Zheng M, Cass GR, Ke L, Wang F, Schauer JJ, Edgerton ES, Russell AG: Source apportionment of daily fine particulate matter at Jefferson Street, Atlanta, GA, during summer and winter. J Air Waste Manage Assoc 2007, 57:228-242.

44. Tranfield EM, van Eeden SF, Yatera K, Hogg JC, Walker DC: Ultrastructural changes in atherosclerotic plaques following the instillation of airborne particulate matter into the lungs of rabbits. Can J Cardiol 2010, 26:e258-e269.

45. Yin F, Lawal A, Ricks J, Fox JR, Larson T, Navab M, Fogelman AM, Rosenfeld ME, Araujo JA: Diesel exhaust induces systemic lipid peroxidation and development of dysfunctional Pro-oxidant and proinflammatory highdensity lipoprotein. Arterioscler Thromb Vasc Biol 2013, 33:1153-1161.

46. Peters A, von Klot S, Heier M, Trentinaglia I, Hormann A, Wichmann HE, Lowel $\mathrm{H}$ : Exposure to traffic and the onset of myocardial infarction. N Engl J Med 2004, 351:1721-1730.

47. Sun Q, Yue P, Kirk RI, Wang A, Moatti D, Jin X, Lu B, Schecter AD, Lippmann M, Gordon T, et al: Ambient air particulate matter exposure and tissue factor expression in atherosclerosis. Inhal Toxicol 2008, 20:127-137.

48. Floyd HS, Chen LC, Vallanat B, Dreher K: Fine ambient air particulate matter exposure induces molecular alterations associated with vascular disease progression within plaques of atherosclerotic susceptible mice. Inhal Toxicol 2009, 21:394-403.

49. Johnson JL, Jackson CL: Atherosclerotic plaque rupture in the apolipoprotein E knockout mouse. Atherosclerosis 2001, 154:399-406.

50. Jackson CL, Bennett MR, Biessen EA, Johnson JL, Krams R: Assessment of unstable atherosclerosis in mice. Arterioscler Thromb Vasc Biol 2007, 27:714-720.

51. Rosenfeld ME, Averill MM, Bennett BJ, Schwartz SM: Progression and disruption of advanced atherosclerotic plaques in murine models. Curr Drug Targets 2008, 9:210-216.

52. Williams H, Johnson JL, Carson KG, Jackson CL: Characteristics of intact and ruptured atherosclerotic plaques in brachiocephalic arteries of apolipoprotein E knockout mice. Arterioscler Thromb Vasc Biol 2002, 22:788-792.

53. Seaton A, Soutar A, Crawford V, Elton R, McNerlan S, Cherrie J, Watt M, Agius R, Stout R: Particulate air pollution and the blood. Thorax 1999, 54:1027-1032

54. Scapellato ML, Lotti M: Short-term effects of particulate matter: an inflammatory mechanism? Crit Rev Toxicol 2007, 37:461-487.

55. Mills NL, Donaldson K, Hadoke PW, Boon NA, MacNee W, Cassee FR, Sandstrom T, Blomberg A, Newby DE: Adverse cardiovascular effects of air pollution. Nat Clin Pract Cardiovasc Med 2009, 6:36-44

56. Nurkiewicz TR, Porter DW, Hubbs AF, Stone S, Chen BT, Frazer DG, Boegehold MA, Castranova V: Pulmonary nanoparticle exposure disrupts systemic microvascular nitric oxide signaling. Toxicol Sci 2009, 110:191-203.

57. Barajas B, Che N, Yin F, Rowshanrad A, Orozco LD, Gong KW, Wang X, Castellani LW, Reue K, Lusis AJ, Araujo JA: NF-E2-related factor 2 promotes atherosclerosis by effects on plasma lipoproteins and cholesterol transport that overshadow antioxidant protection. Arterioscler Thromb Vasc Biol 2011, 31:58-66.

58. Miller MR, Borthwick SJ, Shaw CA, McLean SG, McClure D, Mills NL, Duffin R, Donaldson K, Megson IL, Hadoke PW, Newby DE: Direct impairment of vascular function by diesel exhaust particulate through reduced bioavailability of endothelium-derived nitric oxide induced by superoxide free radicals. Environ Health Perspect 2009, 117:611-616. 
59. Miller MR, Shaw CA, Langrish JP: From particles to patients: oxidative stress and the cardiovascular effects of air pollution. Future Cardiol 2012 8:577-602.

60. Lund AK, Lucero J, Harman M, Madden MC, McDonald JD, Seagrave JC, Campen MJ: The oxidized low-density lipoprotein receptor mediates vascular effects of inhaled vehicle emissions. Am J Respir Crit Care Med 2011, 184:82-91.

61. Hoek G, Krishnan RM, Beelen R, Peters A, Ostro B, Brunekreef B, Kaufman JD: Long-term air pollution exposure and cardio- respiratory mortality: a review. Environ Health 2013, 12:43.

62. Sacks JD, Stanek LW, Luben TJ, Johns DO, Buckley BJ, Brown JS, Ross M: Particulate matter-induced health effects: who is susceptible? Environ Health Perspect 2011, 119:446-454.

63. Shaw CA, Robertson S, Miller MR, Duffin R, Tabor CM, Donaldson K, Newby DE, Hadoke PW: Diesel exhaust particulate-exposed macrophages cause marked endothelial cell activation. Am J Respir Cell Mol Biol 2011, 44:840-851.

doi:10.1186/1743-8977-10-61

Cite this article as: Miller et al:: Diesel exhaust particulate increases the size and complexity of lesions in atherosclerotic mice. Particle and Fibre Toxicology 2013 10:61.

\section{Submit your next manuscript to BioMed Central and take full advantage of:}

- Convenient online submission

- Thorough peer review

- No space constraints or color figure charges

- Immediate publication on acceptance

- Inclusion in PubMed, CAS, Scopus and Google Scholar

- Research which is freely available for redistribution 